aesthetists would surely agree that succinylcholine is hazardous in patients with major burns and spinal cord injuries. The statement, however, that "Except when used for emergency tracheal intubation or in instances where immediate securing of the airway is necessary, succinylcholine is contraindicated in children and adolescent patients," is, in our view, preposterous, and supported by very little data. The recommendation is equivalent to proposing that all children be given a trigger-free anaesthetic, in case they have an undiagnosed susceptibility to malignant hyperthermia! Their advice to use a nondepolarizing blocker is clearly meaningless if a maintenance technique using spontaneous ventilation is deemed optimal by the anaesthetist.

Robin G. Cox MB FRCA FRCPC

Gerald V. Goresky MD FRCPC

\section{Succinylcholine and children (2)}

To the Editor:

Nous recevions récemment une missive (29 octobre 1993) en provenance de la compagnie Burroughs Wellcome Inc. nous informant des nouvelles mises en garde et contreindications intéressant l'emploi de la succinylcholine. Nous fûmes toutefois estomaqués d'y découvrir que la succinylcholine était maintenant contre-indiquée chez les enfants et adolescents sauf pour le contrôle urgent des voies aériennes supérieures. Il faut se rappeler que ce curare de type dépolarisant a vue le jour pour ce qui est de son utilisation clinique en 1949 et demeure encore ajuourd'hui le relaxant musculaire le plus utilisé particulièrement chez les enfants et les adolescents grâce à ses propriétés uniques touchant à la fois la vitesse d'induction du bloc neuromusculaire et sa courte durée d'action. Les risques d'hyperkaliémie décrits par le docteur François Lebel, vice-président aux affaires scientifiques (microbiologiste) chez Burroughs Wellcome Inc. sont connus depuis des décennies mais n'avaient jamais fait l'objet, jusqu’à présent, de communiqué spécial en provenance de cette compagnie.

Audet Romuald MD

Jean Brassard MD

Claude Brousseau MD

Laurent Marceau MD

Jean-Claude Pouliot MD

Jean-François Rouillard MD

Jean-Pierre Baribault MD

Jacques Brochu MD

Georges Desjardins MD

Jean-Guy Patoine MD
Michel Rouillard MD

Camille Thivierge MD

Hôpital de l'Enfant-Jésus

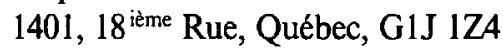

\section{Succinylcholine and children (3)}

To the Editor:

In a recent "Dear Doctor" letter, Burroughs Wellcome Inc., notified Canadian anaesthetists of a change in indications for succinylcholine, it now being "contraindicated in children and adolescent patients" except "when used for emergency tracheal intubation or in instances where immediate securing of the airway is necessary." This suggests that it is not ever appropriate, for instance, to employ succinylcholine instead of a non-depolarizing agent in an adolescent for elective intubation for fear that the succinylcholine might trigger hyperkalemia in patients with a rare undiagnosed myopathy. However, we would suggest that there are some patients for which the airway does not appear to be sufficiently difficult that awake intubation is required, but for which a very short-acting muscle relaxant would seem prudent, just in case intubation turns out to be difficult. To suggest that succinylcholine is contraindicated in this instance may be unwise; many clinicians are far more concerned about an unexpected difficult airway (experienced by all of us on a fairly regular basis) than in a very rare event in apparently healthy children.
D.J. Doyle
H. Yosu
D.J. Opershaw
A.K. Laws
M. Friedlander
C.H. Marryatt
E. Dosch
A.N. Sandler
J. Bradley
G. O'Leary
J. Bradwell
R. Arellano
M.E. Cooke
Department of Anaesthesia
Toronto General Division
The Toronto Hospital
200 Elizabeth Street
Toronto, Ontario M5G 2C4 